\title{
Historical reasons for the focus on broad monetary aggregates in post-World War II Britain and the 'Seven Years War' with the IMF
}

\author{
CHARLES A. E. GOODHART ${ }^{\star}$ and DUNCAN J. NEEDHAM ${ }^{\star \star}$ \\ *London School of Economics \\ **University of Cambridge
}

\begin{abstract}
The British monetary authorities have traditionally focused on broader monetary aggregates than their counterparts elsewhere. The reasons include: the willingness of UK banks to allow customers to make payments by drawing on time deposits, the particularities of the UK approach to managing the national debt and the foreign exchange reserves, and the flow-of-funds system of national accounts developed after World War II. This article outlines these reasons, and explores the implications for the UK's often fractious relationship with the International Monetary Fund during the I950s and I960s. It explains why IMF conditionality on loans to the UK focused on broad aggregates.
\end{abstract}

Keywords: monetary policy, monetary history, International Monetary Fund

JEL classification: B26, E52, Nio

Two main characteristics differentiated post-war British monetary analysis and management from those of most other developed countries. First, monetary targetry in the UK focused primarily on a broad money aggregate, $M_{3}$ or $\mathcal{E}_{3}$, comprising both sight (demand) deposits and time and savings deposits, equally weighted. ${ }^{1}$ This contrasted with procedures in most other countries, which focused on a

C. A. E. Goodhart, Financial Markets Group, London School of Economics and Political Sciences, Houghton Street, London WC2A 2AE, UK. D. J. Needham (corresponding author), Darwin College, University of Cambridge, Silver Street, Cambridge CB3 9EU, UK; email: djn33@cam.ac.uk. The authors are grateful to two anonymous referees for their comments.

${ }^{1} \mathrm{M}_{3}$ comprised currency in circulation with the public (excluding cash in banks' vaults but including non-UK residents' currency holdings) and (sterling and foreign currency) deposits of UK (public and private) residents with UK banks. $\mathrm{fM}_{3}$ comprised currency in circulation with the public and the sterling deposits of UK residents. Currently the focus is on $\mathrm{M}_{4}$, which comprises the UK private sector's holdings of sterling currency, sterling deposits with UK banks, and building society shares, deposits and sterling certificates of deposit. The increasing liquidity of building society shares led to their inclusion 
narrow monetary aggregate, such as $\mathrm{MI}$, and gave either no weight, or less weight (as in Germany) to time and savings deposits. ${ }^{2}$ British practice in this respect derived from longstanding behaviour whereby UK banks have traditionally allowed clients to make payments by drawing on their time deposits. The dividing line in the UK between (monetary) sight deposits and (quasi-money) time and other deposits was therefore more porous than in most other countries. By the same token, and unlike in the USA and Germany, cash and liquidity ratios were applied equally to all deposits.

UK private sector residents' bank deposits in this period comprised the bulk of total bank liabilities, which must equal bank assets. ${ }^{3}$ Focusing on a broad monetary aggregate led naturally to the second distinguishing characteristic of British monetary analysis and management - the credit counterparts approach - since the broad monetary aggregate is the counterpart of bank lending to the public, private and overseas sectors. In contrast, focusing on a narrow monetary aggregate in a flow-of-funds framework would have required assessment of likely flows between sight and other kinds of bank deposits, which were neither easily predictable nor easily subject to any official control.

The credit counterparts approach contrasted with the dominant academic theory of the determination of the money stock from the late I930s, which focused on the money multiplier. This linked the money stock, broad or narrow, to the monetary base provided by the central bank and two ratios: the public's currency/deposit ratio, and the banks' reserve/deposit ratio (Phillips I920; Keynes I930; Meade I934; Sayers I938). Like the flow-of-funds approach, this was derived from a statistical identity, and in neither case could one assume a direction of causation. The main problem with the money multiplier approach has been that almost always, almost everywhere, central banks have chosen to set an official short-term interest rate, not a fixed quantity of base money (that is, prior to reaching the Zero Lower Bound). Consequently, central banks must passively provide just that quantity of base money consistent with the officially chosen short-term interest rate. Therefore, the money multiplier actually works in reverse, determining the monetary base with (broad) money growth influenced, inter alia, by the officially chosen level of short-term interest rates (Goodhart 2009, 20I6, 20I7; Goodhart, Bartsch and Ashworth 2016).

It would have been physically possible for any central bank, including the Bank of England (the 'Bank'), to reverse engines and control the quantity of base money, allowing (short-term) interest rates to fluctuate as they willed. But

in $\mathrm{M}_{4}$ from 1987 ('Measures of broad money', BEQB, 27(2) (May I987), p. 2 I 2, n. 2; Hotson 20 Io, p. 4I).

2 MI comprised currency in circulation with the public and UK private sector residents' sight deposits with UK banks. Before I975, Mi deposits were defined as current accounts against which cheques could be drawn. Public sector deposits were excluded.

3 With due adjustment for changes in non-deposit liabilities such as bank equity. Deposits as a percentage of total clearing bank liabilities rose from 79 per cent in I 880 to 94 per cent in I 966 , peaking at 96 per cent in I953 (Sheppard I97I, pp. I26-7). 
given banks' inelastic demand for base money, fluctuations would most likely have been volatile. In view of the UK's high post-war debt ratio, the fragile structure of the gilts market, with the jobbers (the market makers) being too lightly capitalised, and the need to maintain investor confidence, the authorities, especially the Bank but also HM Treasury, reacted strongly against proposals for monetary control that put financing of the national debt, and the existing structure of money and gilts markets, at risk.

After World War II, British banks were large holders of (mostly short-dated) public sector debt. It was apparent to any careful observer that, if the Bank wanted to maintain a given level of short-term (Treasury bill) rates, the banking system could generate whatever reserve base it wanted. But academic theories, even when wrong, are hard to kill off. The then doyen of British monetary economists, Richard Sayers, retreated from espousing a cash ratio theory to treating the liquidity ratio as the effective fulcrum for monetary control in subsequent editions of his textbook, Modern Banking. ${ }^{4}$ But Bank officials were then just as leery about allowing (encouraging) gilt prices to fluctuate in an uncontrolled fashion (in the hope of managing net debt sales better), so in practice the liquidity ratio multiplier was just as analytically back-to-front as a cash ratio multiplier. ${ }^{5}$ Nevertheless the possibility of some measure of ratio control (exerting pressure on the banks' liquidity ratio with, for example, calls for Special Deposits) remained a concept that cropped up in the British authorities' thinking from time to time. ${ }^{6}$ There was often a degree of confusion in the Bank and Treasury between multiplier analysis (whether via the liquidity or cash ratio), which was taught almost universally in academia, and the flow-of-funds approach which was what the UK authorities, but not most academics, really believed.

We discuss the genesis of the flow-of-funds approach, then in its infancy, below. It was particularly attractive to the UK authorities because it focused on four main economic developments which the authorities regarded as crucial for policy. These were (I) the Public Sector Borrowing Requirement; (2) net sales of public sector debt to the non-bank public, which together, more or less, determined the residual bank lending to the public sector; (3) bank lending to the private sector; and (4) net overseas flows, whose statistical treatment was complex, as we show. If the authorities could control the first three (domestic credit expansion, DCE) then, assuming a stable

4 In the original I938 edition Sayers suggested that the 'customary' 9 per cent cash ratio was 'more rigid' than the liquid assets ratio and that "banks, subject to the supply of "cash" and the public's demand for cash, have absolute control over the volume of deposits' (Sayers I938, pp. 34-5). In the 7th (1967) edition he explained that 'the reader must take it as one of the facts of the current situation, that the operative restraint on expansion of bank credit is the 28 per cent. ratio, while within the total of liquid assets the operators see to it that 8 of the 28 shall consist of cash' (Sayers I967, pp. 38-9).

${ }^{5}$ Bank of England, 'Operations in the gilt-edged market', BEQB, 6(2) (June I966), pp. I4I-8.

${ }^{6}$ Special Deposits were introduced in 1958 and required deposit-taking banks to post a percentage of their gross advances at the Bank during times of credit restraint. 
demand for money function, net external flows and reserve accumulation could be controlled.

In practice none of these three components of DCE could be closely controlled. Once the annual budget had set expenditure plans and tax rates, public sector expenditures depended on how strictly the Treasury could hold the spending departments, and the local authorities and nationalised industries, to their prior plans, while tax receipts were endogenous to the economic cycle. The authorities were unwilling to force gilt sales onto a weak market, partly out of concern for the solvency of the jobbers, partly because they feared that expectations would be auto-regressive, and partly for fear of damaging longer-run confidence about the safety of investing in gilts. So gilt sales tended to come in bursts (at unpredictable times), interspersed with periods of much lower, or even negative sales.

That left the third major component, bank lending to the private sector. But such lending was not seen as elastic in response to the scale of variation that the authorities were prepared to countenance in official short-term rates, i.e. Bank rate, given the various factors, external and domestic, weighing on the Chancellor's interest rate decisions. All that meant in practice, during the years from 1945 until Competition and Credit Control in I97I, was that the authorities (led by the Treasury, unhappily followed by the Bank) would reach for directly applied ceilings on bank lending to the private sector whenever there was a perceived need for a check to domestic credit and monetary growth.

The International Monetary Fund (IMF), under the analytical direction of Jacques Polak, preferred a simpler ('Western Hemisphere') model based on the money multiplier approach. Faced with the UK authorities' insistence that such a model was inappropriate for the UK, the Fund, after lengthy discussion described below, became prepared to work with the UK authorities within the context of a flow-of-funds model. ${ }^{7}$ Indeed, the Fund insisted at the time of heavy UK drawing in 1969 that DCE, as defined above, could, and should, be limited and controlled.

By the end of the I960s, the monetary authorities in the UK had firmly tied themselves to the joint position of focusing on a broad money target and using a flow-offunds analysis for forecasting and (attempted) control purposes. This was not, of course, the end of the story. The expansion of the money stock in the years I97I-4 was more exaggerated in broad money $\left(\mathrm{M}_{3}\right)$ than in narrow money (as recurred in I980-I). This led British monetarists, and much of the Conservative Party, to focus on $M_{3}$ as the underlying cause of the subsequent inflation in the mid I970s, while it led some Bank officials from time to time to regard MI as a truer measure of the 'thrust' of monetary policy.

7 A 1965 internal Bank paper, drafted by Andrew Bain, had set out just such a model: Bank of England Archive, London (hereinafter, 'BOE'), 6A50/I, A. D. Bain, 'Some factors affecting the money supply', 9 December I965. With the agreement of the Bank this is available at www.centreforfinancialhistory.org 
Much of the history of the conduct of monetary policy during these years has already been set out, not least in the official histories of the Bank of England by Fforde and Capie (Fforde I992; Capie 2010). The particular contribution of this article lies instead in the detailed historical study of the largely statistical discussions between the Bank and the IMF, whereby the Bank eventually persuaded a reluctant Fund that monetary conditionality, and later targets (whether for domestic credit or the money stock), in the UK should be based on broad aggregates.

\section{II}

In April I 86I, launching its inaugural half-yearly banking supplement, the Economist newspaper recommended that the 'perfect Report of a Joint Stock Bank' should state 'what are the deposits, distinguishing between those held at call and those which are to be repaid only at the expiration of a certain stipulated notice'. 8 As René Higgonet points out, however, 'most banks did not distinguish between current accounts and fixed deposits' in the nineteenth century (Higgonet I957, p. 333). Even after the Economist first aggregated the banking data in October I877, and began publishing monthly figures for (most of) the London joint stock banks from August I89I, it was difficult to distinguish current and deposit accounts. ${ }^{9}$ As financial journalist Hartley Withers later explained: 'if a customer wished to remove deposit funds immediately, very few bankers would refuse to permit him to do so'. ${ }^{10}$ This remained the position in I930 when the managing director of the Midland Bank, Frederick Hyde, explained to the (Macmillan) Committee on Finance and Industry:

We must bear in mind that our deposits are in a very considerable part payable on demand, and even those deposits that are fixed for a period may be payable on demand by arrangement with the depositor. ${ }^{11}$

Nonetheless, considering 'exact quantitative knowledge concerning the chief elements of the monetary and financial system' to be 'of the utmost importance', the Macmillan Committee obtained, and published, a breakdown of current accounts ('sums payable on demand') and deposit accounts ('sums payable after a date or notice') at the ten London clearing banks and the six Scottish banks since I9I9 (Macmillan Committee I93I, pp. I74, 283-95; Capie and Webber I985, pp. 259-60). On the Committee's recommendation, disaggregated data continued to

${ }^{8}$ James Wilson (proprietor) and Walter Bagehot (editor from I86I) wanted the Economist to be 'the leading statistical journal of its day' (Dudley Edwards I993, p. 274; Economist, 6 April I 86I, pp. 366-7).

9 In January I 89I, following the Baring crisis, Chancellor of the Exchequer George Goschen called for the joint stock banks to provide monthly financial statements (Goschen I905, pp. I I6-I7); 'Statement of bank accounts in a summarised form', Economist, 20 October 1877 (supplement), pp. 3-5; 'The first of the monthly bank accounts', Economist, 8 August I89I, p. I03 I.

10 The Post Office Savings Bank also permitted depositors to withdraw time deposits on demand (Sheppard I97I, p. 8; Withers I9I0, p. I02).

11 Macmillan Committee (I93 I), p. 37. 
be published, first in the Bank of England Statistical Summary and then in the Monthly Digest of Statistics, as well as the Economist. ${ }^{12}$ The divide between current and deposit accounts remained porous, however. As Sayers pointed out in I938:

banks will transfer balances from one of their own classes to the other without hesitation - they leave the distribution of deposits entirely in their customers' hands. The banks decide the total volume of deposits; but the public, directly at least, decides the distribution between the Cash Deposits and Savings Deposit categories. ${ }^{13}$

This remained the case after the standardisation of seven-day terms for deposit accounts in I955 (Radcliffe Committee I959a, paras I3 I-2; Wadsworth I973, p. I25). In June 1958 the National Institute of Economic and Social Research included in its definition of the money supply 'deposit accounts in the joint stock banks, the restrictions on transfer being such that the accounts can be regarded as de facto transferable "without restriction", ${ }^{14}$

\section{III}

In I 86I, the Economist also warned against judging a bank primarily by the adequacy of its capital. Rather:

we should add together all the liabilities of the bank - its circulation, its drafts, and its deposits: see what the total is carefully; and then we should compare it with the amount of cash, loans to bill brokers, Government securities, and other immediately tangible and convertible assets which the bank has in hand. If the available money bears a good proportion to the possible claims, the bank is a good and secure bank. ${ }^{15}$

On the question of 'the specific proportion between the cash reserve and the liabilities of the bank' the newspaper refused to 'lay down any technical or theoretical rule'. The cash ratio must be allowed 'to vary in some degree with the nature of the bank's business'. Seventy years later, the Macmillan Committee largely agreed:

The monetary system of this country must be a Managed System - It is not advisable, or indeed practicable, to regard our monetary system as an automatic system, grinding out the right result by the operation of natural forces aided by a few maxims of general application and some well worn rules of thumb. ${ }^{16}$

12 The Bank of England Statistical Summary was produced for internal use from I926 and circulated amongst other central banks from I927. Enlarged in 1928, it circulated amongst certain government departments from I930, and was published from 1932 on the recommendation of the Macmillan Committee (BEQB, I6(4) (December I976), p. 437; Sayers I967, p. 383 n. 2).

13 Between August I936 and May 1937 the Federal Reserve increased the reserve requirements for member banks, from 3 per cent to 6 per cent for time deposits and from 7-I 3 per cent to I4-26 per cent for demand deposits (depending on location) (Board of Governors of the Federal Reserve System I943, p. 400; Sayers I938, p. 248).

14 Radcliffe Committee (I959b), vol. 3, p. 5, n. I.

15 Economist, 6 April i86I, pp. 366-7.

16 Macmillan Committee (I93 I), para. 280. 
According to the Committee, the monetary authorities should manage the price level by changing 'the quantity and terms of credit' principally by adjusting Bank rate ('a most delicate and beautiful instrument'). ${ }^{17}$ As Sayers wrote in 1938 , 'the tendency nowadays is to regulate cash ratios not in the interests of bank liquidity but in the interests of central bank control over aggregate bank deposits' - what officials referred to as the 'Macmillan process'. ${ }^{18}$ But unlike the US Federal Reserve, which required member banks to keep 6 per cent of their time deposits and I4-26 per cent of their sight deposits in cash, the UK monetary authorities did not differentiate between sight and time deposits (Sayers I938, pp. 43-4 and 254-8). There was no incentive, from a reserves perspective, for British banks to steer customers towards deposit rather than current accounts.

The requirements of wartime finance forced what the Midland Bank identified as 'a radical alteration of the "cause and effect" relation between bank cash and deposits' ${ }^{19}$ As government revenues fell short of current expenditures, (and after sales of British government securities to the non-bank public and foreign loans), the Exchequer was forced to borrow from the banks, largely in the form of bank purchases of additional Treasury Deposit Receipts and Treasury bills. The counterpart of such additional loans to the public sector was mainly higher private sector deposits (via government expenditure), which required the banks to maintain higher cash reserves to preserve their (informal) cash ratios. ${ }^{20}$ To support the higher level of deposits necessary for increased government borrowing from the banks, the Bank had to supply more cash to the banks through open market operations. This was the reverse of the 'Macmillan process', with cash reserves now determined by the volume of aggregate deposits. $^{21}$

With the national debt peaking at 238 per cent of GDP after World War II and the banks extremely liquid, the authorities were forced to extend wartime financial repression. In 1946 the cash ratio was formalised with the clearing banks required

17 Clearing banks' liquidity ratios rose from c. 20 per cent in the I 88 os to over 30 per cent during World War I before declining to $c$. 20 per cent during World War II. While there was no statutory minimum, the Bank indicated in I95 I that 'it would be totally unacceptable if the ratio dropped below 25 per cent' (Turner 20I4, p. I82; Sheppard I97I, pp. I26-7; Macmillan Committee I93 I, paras. 2 I I, 2 I 8 and 303$)$.

18 Sayers (I938), p. 44; The National Archives, London (hereinafter 'TNA'), T233/48 I, 'D. P. T. Jay to R. S. Cripps', 28 February I948.

19 Nevin and Davis suggest causality was reversing with the 'open back-door' policy of the late I930s, whereby the banks could replenish cash reserves by selling large volumes of Treasury bills to the Bank at market rates without reducing advances (Nevin and Davis I970, pp. I4I-2; 'The changing shape of Britain's monetary system, part I: I93 I-45’, Midland Bank Review (November I947), p. 4).

20 Treasury Deposit Receipts (TDRs) were introduced as a wartime expedient in July I940 and existed until I952. The London clearing, Scottish, and two overseas banks were instructed to place nontransferable deposits, usually of six months, with the Treasury. TDRs could be switched for gilts or sold to the Bank for 'emergency purposes' so were less liquid than Treasury bills (Allen 20I2, p. 8 I 2 n.).

21 TNA, T233/48I, 'E. E. Bridges to R. V. N Hopkins', 27 February I948. 
to hold 8 per cent of their total deposit liabilities in notes, coin, and reserves at the Bank. ${ }^{22}$ With the banks holding so many near-money assets, and the Bank prepared to monetise these on demand, there was no question of controlling lending via the cash ratio, a notion described as 'risible' by one former Bank economist. ${ }^{23}$ In order to keep interest rates and the cost of government finance stable, the Bank continued to supply whatever cash the banks demanded. ${ }^{24}$ In I95 I, the cash ratio was supplemented with a request that the clearing banks hold 28-32 per cent of their total deposits in liquid assets: cash, money at call with the discount houses, eligible commercial bills, and UK Treasury bills. ${ }^{25}$ These measures had little to do with prudential financial management. Nor were they attempts to regulate bank lending through the operation of a multiplier. As the Governor admitted in 1957, they were principally about directing the nation's savings into government debt so the Bank could avoid 'a continual state of anxiety as to how the Government's requirements for finance for the following week were going to be met'. ${ }^{26}$ When the liquidity ratio was formalised in I95I, the banks were 'forced' to switch about \&500 million of Treasury bills for 'serial funding stock'. ${ }^{27}$ This reduced their liquid assets from 39 per cent of total deposits to 32 per cent (Radcliffe Committee I959a, para. 406).

The liquidity ratio was consistent with the arrangements developed during the 'cheap money' period. These arrangements rested on three (non-statutory) agreements:

I. An informal, but effective, clearing bank cartel that fixed deposit and lending rates in return for a monopoly on the payments system. This was one of the factors that enabled the authorities to continue their direct repression of bank lending during times of strain. ${ }^{28}$

2. A discount house/clearing bank agreement that gave the discount houses a virtual monopoly over the Treasury bill tender in return for an agreement not to compete with the clearing banks for deposits. ${ }^{29}$ (The clearing banks financed the deposit houses with 'money at call' at a pre-agreed margin.)

22 BEQB, 2(4) (December I962), p. $25 \mathrm{I}$.

23 Former Bank economist Anthony Hotson cites M. D. K. W. Foot, C. A. E. Goodhart and A. C. Hotson, 'Monetary base control', BEQB, I9(2) (June I979), pp. I49-59 in Hotson (20I7), p. I47.

24 'The management of money day by day', BEQB, 3(I) (March I963), pp. I5-2 I.

25 This included the cash ratio (BEQB, 2(4) (December I962), p. 252).

26 Radcliffe Committee (I960), para. 262 I; Nobay (I973), p. 48.

27 The EI billion 'serial funding stock' issued (of which about £,500 million was sold to the banks) in November I95 I comprised three tranches: ¿450 million maturing in November I952, £200 million in November 1953 and f350 million in November I954. Short maturities meant 'apart from nomenclature, the forced funding amounted to little more than a rise in the rate of interest paid to the banks for holding floating debt' (Dow I970, p. 230; Allen 20I4, pp. 27, 56).

28 TNA, T326/86I, Bank of England, 'The clearing banks' collective agreements', 20 August I968.

29 For the I930s origins of the discount house/clearing bank agreement, see Balogh (I950), pp. I32-5; Fletcher (I976), pp. 49-5I. 
3. A Bank/discount house agreement that the discount houses would cover the Treasury bill tender in return for a monopoly on the Bank's lender of last resort facilities.

In the post-war period, the goal was to maximise sales of government debt at minimal cost, while all the time maintaining the value of sterling. The authorities had to sell significant quantities of government debt simply to finance maturing stock before they could begin to tackle new Exchequer funding needs. Quite apart from the theoretical objections, shifting to a system that relied on more volatile interest rates to exercise control through a cash ratio would have imperilled the Bank's ability to finance the national debt, its primary function since its foundation in I694. There seemed little point in risking a collapse simply to refashion the monetary infrastructure along neater theoretical lines.

\section{IV}

In his I956 Budget statement, Chancellor Harold Macmillan complained that 'some of our statistics are too late to be as useful as they ought to be. We are always, as it were, looking up a train in last year's Bradshaw.' ${ }^{30}$ Macmillan was partly referring to the forecasts that had preceded R. A. Butler's expansionary Budget the year before. ${ }^{31}$ The subsequent boom had required a rigorous credit squeeze with Butler requesting a 'positive and significant' reduction in bank advances just three months after his Budget. ${ }^{32}$ In March I956 the high-level civil service Economic Steering Committee asked the Working Party on Statistics for Employment Policy to consider whether existing banking and financial statistics were adequate for the formulation and measurement of monetary policy. ${ }^{33}$

While the impetus came from Ministers, officials recognised in 1956 that better financial statistics might contribute "raw material for "flow of fund" analyses'.34 The Bank described the technique as:

30 Bradshaw's railway timetables were published annually from I839 to I96I; HC Deb, I7 April I956, vol. $55 \mathrm{I}$, c. 867 .

31 Butler may also have been influenced by the proximity of the May I955 General Election, called four days before his Budget. The index of production had shown little increase since the third quarter of I954, leading Treasury officials to conclude that 'the misleading implications of the preliminary figures for stock increases in I954 draw particular attention to the need for (a) knowing what statistics you require, (b) having those you must require as reliable and as early as possible' (TNA, Ti 59/9, 'Schedule of subjects to be covered in the background papers', February I959; Dow I970, p. 79, n. 5).

32 The clearing banks agreed to reduce their advances io per cent by the end of I955 (Allen 20I4, pp. II2-I3; HC Deb 25 July I955 col. 544 cc. 824-34; Fforde I992, p. 640).

33 The Economic Steering Committee was chaired by the Permanent Secretary to the Treasury and comprised the Permanent Heads of the other departments (TNA, CAB I39/459, Central Statistical Office, 'Note of an informal meeting', I4 June I956).

34 BOE, EID4/ 56 , Statistics Office, 'Review of Banking and Financial Statistics', i I September I956. 
a logical extension of the more familiar system of national accounts: it covers the transactions in financial assets and liabilities which accompany income and expenditure... by mapping out the financial transactions by sectors, it draws attention to the ways in which such aggregates as an increase in the money supply or, more generally, in liquidity can be built up. (Bank of England I972, p. 7) $)^{35}$

National income statements aggregate flows during a particular period; flow-of-funds matrices 'set out the particular routes along which funds pass between the sectors' capital accounts in a particular period' (Bank of England I972, p. Io). As Andrew Bain points out, while the matrices provide no behavioural explanations of why funds may be flowing in a particular direction, they forge a link between monetary policy and demand management (Bain I973, p. I055). ${ }^{36}$

By November I956, the Central Statistical Office (CSO) had produced rudimentary flow-of-funds matrices. ${ }^{37}$ Within the Bank, John Fforde described this as 'pioneer work' which would shed further light on the growth of the money supply, an increasing Treasury preoccupation under Peter Thorneycroft (Chancellor from January I957) since 'the change in government borrowing from the banking system is then combined with the change in private borrowing from that system to give us the change in money supply'. ${ }^{38}$ Deputy Governor Humphrey Mynors commented 'this looks to me like a Sputnik, not yet at the moon, but navigating in a part of the universe which man has not yet reached. Surely capable of development?'39 In February I958 Economic Trends introduced graphs of the money supply defined as 'Total of (I) deposits at London Clearing Banks and Scottish Banks (less collections and identifiable items in transit), (2) deposits at the Bank of England (other than "Bankers"), (3) currency in circulation with the public'. ${ }^{40}$ This was also the definition used in the I958 Economic Survey. ${ }^{41}$

The Working Party's inquiry was overtaken by the Committee on the Working of the Monetary System (the 'Radcliffe Committee'), announced in April I957 in response to the failure of tighter monetary policy to contain the Butler boom. ${ }^{42}$

35 See also de Bonis and Gigliobanco (2012), pp. I 5-49.

36 See also Capie (2010), p. 28.

37 The CSO's work predates M. W. Holtrop's I957 IMF paper, cited by Batini and Nelson as the origin of the credit counterparts approach in the UK. Holtrop was president of De Nederlandsche Bank, which employed flow-of-funds analysis from I95 I (Steele 20I4, p. 6; Batini and Nelson 2005, p. 3 I; BOE, EIDı3/r, Central Statistical Office, 'Flow of funds in the United Kingdom I948 and I954', I4 November I956).

38 BOE, EID I3/I, J. S. Fforde, 'Your query about statistics of investment', 22 May I957; BOE, EID I3/I, J. S. Fforde, 'What happens to the surplus savings of the private sector', 27 May I958.

39 BOE, EID I3/I, 'W. M. Allen to H. C. B. Mynors' (annotation), i 8 June I958.

40 This definition was agreed by a working party of Bank, HMT and CSO officials; Economic Trends, no. 52 (February I958), pp. iv-vi.

41 HM Treasury, Economic Survey 1958, Cmnd 394 (London: HMSO, I958), p. 45.

42 In March I956 Sir Robert Boothby MP suggested a 'new Macmillan Committee' to Chancellor Harold Macmillan, who delayed while the credit squeeze played out (BOE, GI/I3I, 'Extract from the Deputy Governor's memo', 9 March I956). 
The Radcliffe Committee was equally enthusiastic about flow-of-funds analysis, defining the following objectives:

(i) to allow the framework of the financial structure within which monetary changes take place to be seen in more precise quantitative terms;

(ii) to give the earliest possible indication of the movement of liquidity and of the way in which monetary pressure on demand would be likely to take effect;

(iii) to give the earliest possible indication of the movement of demand in each part of the economy, and so enable the pressure of demand to be regulated satisfactorily. (Radcliffe Committee I959a, para. 798)

The Committee believed that financial statistics should be 'capable of being fitted together so as to show the total movement of funds, not merely the flow through individual financial institutions' (Radcliffe Committee I959a, para. 865). As the Bank noted: 'The Radcliffe Committee's preoccupation with liquidity leads them to give particular attention to the flow of short-term funds and to the statistics of banks as "the largest suppliers of liquid funds".'43 The Committee requested data on 'the current flows of funds from the financial sector as a whole to the other major sectors of the economy... [since] one of the principal objects of monetary analysis [was] to examine the interactions of these sectors on one another through financial transactions' (Radcliffe Committee I959a, paras. 808-9). Given the importance of 'clean' data to flow-of-funds analysis, the report gave detailed statistical recommendations, based largely on evidence submitted by the National Institute of Economic and Social Research (Alford I986, p. 6I). These chimed with the earlier work of the Working Party on Statistics for Employment Policy. ${ }^{44}$

Annual flow-of-funds accounts were produced from I960. ${ }^{45}$ In September I 962 Economic Trends explained that the comprehensive nature of national income accounts and their analysis into sectors have made these a suitable framework for presenting the main "flow" items and for linking the "real" and financial accounts". 46 This was reflected in the sector classifications: Public Sector, Private Sector, and Overseas Sector. ${ }^{47}$ As the authors explained:

In the United Kingdom it is intended to avoid changing the present conventions in the national income accounts, such as those affecting sector boundaries and the definitions of the gross national product, when adding the extra financial tables to the national income

43 BOE, EID4/56, Statistics Office, 'Radcliffe Report: Recommendations on banking statistics', 2 I September I959.

44 Radcliffe Committee (I959b), vol. 3, pp. 3-27.

45 TNA, CAB I 39/6I 8, Bank of England, 'Financial statistics: the present position and suggested developments', 23 July I968; 'Financial surpluses of the private sector', BEQB, I (December I960), pp. $2 \mathrm{I}-9$.

46 'Developments in home financial statistics', Economic Trends, I07 (September I962), p. xi.

47 Official estimates of national income and expenditure for the United Kingdom were first published in I94 I (An analysis of the sources of war finance and an estimate of the National Income and Expenditure', Cmnd 626I, London: HMSO, I94I). 
accounts - at least until considerable practical experience with the new figures has been obtained. (Economic Trends, September 1962, p. xi).

'Scattered' flow-of-funds matrices were published in September I963 in Financial Statistics and the Quarterly Bulletin, and were 'centralised' in the I964 National Income Blue Book (Alford I986 p. 36, n. 2; Bjork and Offer 2013, p. 5). There was quarterly analysis in Financial Statistics from December I 964 and the Quarterly Bulletin from March I965, with more detailed analysis and a new table setting out 'the factors determining changes in the money supply' in Financial Statistics from June I966. ${ }^{48}$ By I968 the flow-of-funds matrices were being used to prepare financial forecasts to test the assumptions underlying the national income forecasts (Berman and Cassell I968, p. xiv). In March I969, the prospect of tougher IMF loan criteria generated 'severe pressure for earlier financial information in the near future'. ${ }^{49}$

\section{V}

The IMF had been developing its own flow-of-funds approach based on a narrower definition of the money supply (Dorrance I955; Polak I959; Polak and Boissonneault I960). In 1956, director of research Jacques Polak defined 'money' as 'an entry, or combination of entries, on the liability side of the balance sheets of the banking system' (Polak I957, p. II). Recognising the arbitrariness of the distinction between current accounts and deposit accounts in countries such as the UK, he nonetheless concluded, from a theoretical perspective, that current accounts and the liabilities of the central bank were 'monetary liabilities' while deposit accounts ('quasi money') were not. On the asset side, he divided the 'quantity of money' in two: 'money of external origin' - the (net) foreign assets of a country's banking system; and 'money of domestic origin' - the domestic assets of a country's banking system. His analysis proceeded on the assumption that the income velocity of money was constant, and that 'domestic credit expansion' was exogenous, that is, 'credit expansion is subject to the responsibility of the banking system'. ${ }^{50}$ From there followed his assertion that excessive domestic credit expansion was the primary cause of balance of payments deficits. These assumptions would put the Fund on a collision course with the UK monetary authorities, accustomed to treating bank credit as a passive variable that responded to the short-term requirements of the

48 In March I966 Financial Statistics included a new table for the money supply that included UK residents' deposits with the accepting houses and overseas banks (both outside the clearing bank interest rate cartel). These had grown from 3 per cent of domestic bank deposits in I955 to I I per cent by 1965 (Central Statistical Office, Financial Statistics, no. 47 (March I966), p. 56; Financial Statistics, no. 32 (December I964), pp. 4-I3 and p. I06; Bell and Berman I966, p. I 5 I; 'Analysis of financial statistics', BEQB, 5(I) (March I965) pp. I6-29; Financial Statistics, no. 50 (June I966), pp. 6-8 and p. 58).

49 By March I969, CSO officials were anticipating DCE conditionality (TNA, CAB I 39/6 I 8, 'Meeting on developments in financial statistics to be held on Wednesday I9th March', i 8 March I968).

50 Polak agreed these assumptions were unrealistic but argued they provided 'a clear gain in clarity' (Polak I957, p. I3). 
public and private sectors, and who believed the velocity of circulation to be unstable (Radcliffe Committee I959a, para. 39I).

The Fund had been publishing the current and deposit accounts of the London clearing banks in International Financial Statistics (IFS) since I948. ${ }^{51}$ In 1955, with some fanfare, it relaunched IFS with a new 'Monetary Survey', recasting and standardising the financial statistics of twelve member states (although not yet the UK) to provide a 'ready-made analysis' that would reveal 'the proximate causes of changes in the money supply'. ${ }^{2}$ The UK money supply was defined as currency and the current accounts (but not deposit accounts) of the London clearing banks. ${ }^{53}$ While there had been some communication over the new presentation, the Bank was perturbed:

We were...very surprised and disturbed to see them burst into print in the January issue of IFS with an incomprehensible economic introduction and the implied promise that this form was to be extended to the UK. The Fund Staff have clearly badly jumped the gun, and it is now mainly a question of finding the best way of undoing the damage. ${ }^{54}$

These were the opening manoeuvres in what Bank officials later referred to as the 'Seven Years War' over UK monetary statistics.

The first problem was doctrinal, reflecting the British emphasis on liquidity rather than the money supply. If the money supply was relatively unimportant to demand management, figures purporting to identify the causes of changes in the money supply could be misleading. ${ }^{55}$ There were also a host of technical problems with the Fund's presentation of the UK monetary statistics. The first involved the treatment of the Exchange Equalisation Account (EEA), set up in 1932 to manage the UK's gold and foreign currency reserves following sterling's exit from the Gold Standard (Howson I980). While day-to-day management lay with the Bank, ownership of the account lay with HM Treasury (the public sector). ${ }^{56}$ The EEA was financed primarily through the issue of Treasury bills; an influx of reserves would usually require

51 Article VIII, section 5 of the IMF's I944 Articles of Agreement charged the Fund to 'act as a centre for the collection and exchange of information on monetary and financial problems, thus facilitating the preparation of studies designed to assist members in developing policies which further the purposes of the Fund'.

52 The 'Monetary Survey' was launched at a party attended by senior IMF officials and publicised in the IMF's 'Inter fund news'; BOE, EID 3/363, Sir R. Makins, 'Monetary Disturbance' (telegram), 2 I March I955; BOE, EID 3/363, F. J. Portismore, 'International Financial Statistics', 23 March I955; BOE, EID 3/363, W. M. Allen, 'New IFS statistics', 27 July i955 (emphasis added); E. Hicks, 'IFS Monetary Surveys', International Financial Statistics, 8(I) (January I955), pp. iii-vii

53 IFS, 8(I) (January I955), pp. I32, I 35 and I66.

54 BOE, EID 3/363, 'IFS (Harcourt's letter of 2nd February)', I4 February I955.

55 BOE, EID 3/363, W. M. Allen, 'International Financial Statistics', 20 February I959.

56 Bank ownership of the EEA would have created legal difficulties over the publication of the weekly Bank Return and accounting problems over the distribution of profits. The primary reason, however, was that 'in the state of opinion at the time this was far too important a function to be otherwise than obviously under direct government control' (Sayers I938, p. I96 (emphasis in original)). 
the authorities to sell more Treasuries, that is, a rise in the reserves was generally associated with an increase in the government's gross liabilities. ${ }^{57}$ The impact on the money supply would depend upon who bought the Treasury bills. ${ }^{58}$ If the commercial banks bought them, their liquidity ratios would rise (although their cash ratios might fall) and it is likely that the broad money supply would increase; if the nonbank private sector bought them, bank lending and the broad money supply would probably be less affected.

In its efforts to standardise the UK's statistics with those elsewhere, and to forge a reliable link between the balance of payments and the monetary sector, the Fund wished to include the EEA in the banking sector of the UK economy ('as if it was financed by the Bank'). ${ }^{59}$ IMF officials treated sterling payments from the government to the EEA (to finance increases in the reserves) as reductions in its net liabilities to the banking sector, i.e. a rise in the reserves implied a decrease in the government's gross liabilities. ${ }^{60} \mathrm{~A}$ change in the reserves might also produce a change in the non-bank private sector's holdings of Treasury bills with little impact upon the government's liabilities to the banking sector. Also, with the Bank holding other sterling area countries' reserves and foreigners' balances for international trade, the EEA could fluctuate for reasons that had little to do with the UK economy. The Fund's approach might identify a monetary stimulus from the government to the banking system where none had taken place. As adviser to the Governors (and former IMF assistant director of research) Maurice Allen pointed out, 'the IFS presentation does not correspond to the complexities of our overseas banking activities and can produce nonsense results when applied to UK figures' ${ }^{61}$

There was a related problem with the Fund's proposed treatment of the Bank's Issue Department. Elsewhere, issue departments largely confined their activities to issuing bank notes and passing the proceeds on to their governments so could logically be treated as part of the public sector. But the Bank of England's Issue Department also managed the national debt. This required the department to hold significant and changing amounts of British government securities. As a consequence, the Fund proposed to treat the Issue Department as part of the UK banking sector.

57 The EEA was initially financed in 1932 with $£ 20$ million transferred from the Treasury's Exchange Account (previously used to repay war debts to the USA) and _, I 50 million raised from taxation The US Exchange Stabilization Fund, less active during this period, remained self-financing until the early I960s with $\$ 2$ billion of the proceeds from the I934 revaluation of the US gold reserves (Bordo, Humpage and Schwarz 2015, pp. 6I-3).

58 Roger Alford spent two years on secondment at the Bank in I960-2 and touches briefly on the complexities of EEA finance in Alford (2009), p. 279.

59 The IMF included its estimates of the French Fonds de Stabilisation des Changes in the monetary sector; IFS, 8(I) (January I955); BOE, EID 3/364, M. J. Thornton, 'The IMF monetary survey', is June I96I.

60 BOE, EID 3/363, 'J. P. Burman to M. J. Thornton', I January i96o.

61 BOE, EID 3/363, W. M. Allen, 'New IFS statistics', 27 July I955. 
But in the UK, monetary policy was debt management policy. ${ }^{62}$ The authorities influenced the monetary system mainly through operations on public sector debt, with Bank rate directed primarily towards the exchange rate. The Bank described the Fund's proposal to place its debt management operations in the banking sector as leaving the monetary authorities looking like 'Hamlet minus [the] Prince'. ${ }^{63}$ Furthermore, placing the Issue Department in the banking sector would require the authorities to reveal the extent of the Bank's holdings of British government securities. ${ }^{64}$ This was market-sensitive information that might hinder the Bank's ability to execute monetary policy. ${ }^{65}$

A further problem was that the information required to show the origins of changes in the money supply would require greater disclosure from all sectors comprising the 'monetary system' as defined by the Fund: the Bank, the clearing banks, and 'other financial institutions' such as the building societies, the Trustee Savings Bank and the Post Office Bank. This would place an unwelcome statistical burden on the entire financial sector. The I946 Companies Act permitted the clearing banks to withhold information about their reserves, which they tended to keep in 'Other Accounts'. The IMF's new approach might reveal information about these reserves, especially embarrassing for the large clearing bank rumoured to have suffered heavy losses between I947 and I95I. ${ }^{66}$ As Maurice Allen pointed out, 'for the IFS to be in a position to give the analysis of the proximate causes of the change in money supply, they would need to know more than we would want to tell them'. ${ }^{67}$

Despite the Bank's preparedness to 'go into action' with the IMF's Statistics Division, a lack of support from other countries necessitated a truce which involved the Fund publishing the UK statistics in the pre-1955 format until both sides could agree a mutually acceptable format. ${ }^{68}$ After several further engagements, a delay while the Radcliffe Report's statistical recommendations were implemented, and a 'pleasant and profitable visit' to Washington by the Bank's head statistician, the

62 The Radcliffe Committee explained that monetary action and debt management were 'one and indivisible; debt management lies at the heart of monetary control, and it is essential that this unity should be adequately reflected in our institutional arrangements' (Radcliffe Committee I959a, para. 603).

${ }^{63} \mathrm{BOE}, \mathrm{EID}_{3} / 364$, 'M. J. Thornton to J. S. Fforde', 28 July I96I.

${ }^{64}$ Under the provisions of the Currency and Bank Notes Act, I939, differences between the Issue Department's assets and its liabilities (the banknote issue) automatically flowed between the Issue Department and the EEA (Radcliffe Committee I959b, vol. I, p. I3).

65 In evidence to the Radcliffe Committee, W. W. Riefler of the US Federal Reserve explained that the Americans were more comfortable revealing the Fed's US Treasury dealings to the market (Radcliffe Committee I959a, para. 582).

${ }^{66}$ In I96I, the banks were assured that 'nothing will be published which, directly or inadvertently, could reveal the size or movement of any bank's inner reserves' (TNA, CAB I08/367, Bank of England, 'Statistics from banks and discount houses', i6 June i96I; TNA, Ti59/i6, R. T. Armstrong, 'Banking statistics', November 1958).

${ }^{67}$ BOE, EID 3/363, W. M. Allen, 'New IFS statistics', 27 July I955.

${ }^{68}$ Minor changes were made to the presentation of the UK figures in the October 1955 IFS; BOE, EID 3/363, 'A. M. Stamp to W. M. Allen and J. B. Selwyn', 2I July I955. 
Bank declared victory when the Fund's statisticians fell in to line with the UK presentation of monetary statistics in the August I962 IFS. ${ }^{69}$ The EEA and the Issue Department were excluded from the banking sector, which was defined as per the Bank of England Quarterly Bulletin. Current and deposit accounts were both treated as 'money'. As the Bank's deputy head of statistics noted:

I am surprised that the IMF have capitulated on the current/deposit A/C battle. I would have thought that any understatement of 'Money' that would arise from excluding Deposit Accounts (and, with them, some balances which are in practice operated on as demand deposits) would be considerably less than the overstatement arising from inclusion of Deposit accounts (and, with them all the truly savings accounts) - i.e. that Deposit Accounts contained more savings accounts than disguised deposit accounts. However, the fund having accepted defeat, it would be silly to turn the board around and start the game all over again. ${ }^{70}$

The Fund had finally acknowledged what Walter Bagehot had known a century before, that 'the distinction between current and deposit accounts in the UK is not as marked as implied by the treatment of one as Money and the other as QuasiMoney; deposit accounts are in practice frequently treated by the holders as indistinguishable from current accounts' ${ }^{71}$

If the dispute with the Fund had been confined to the presentation of UK monetary statistics, it might have remained 'a statisticians' wrangle'. ${ }^{72}$ However the UK was fast becoming the largest single user of IMF facilities. In December I956, the UK drew \$56I.47 million and secured an additional \$738.53 million stand-by facility. ${ }^{73}$ There were further drawings in August I96I (\$I,500 million), November I964 (\$I,000 million) and May I965 (\$I,400 million). ${ }^{74}$ Initially these facilities came with few conditions attached, partly because UK officials could invoke sterling's reserve currency status. ${ }^{75}$ As one Treasury official noted in I959, 'it would be repugnant to the dignity of a country of the UK's status' to have conditions applied to IMF loans. ${ }^{76}$ This was not the case with less-developed nations where, to increase the probability of successful economic adjustment (and the IMF's chances of getting its money back), loans were granted 'only after substantial investigation of the

69 BOE, EID 3/364, 'U. Tan Wai to J. B. Selwyn', I 3 January I96I; IFS, I 5 (8) (August I962), p. 265.

70 BOE, EID 3/364, 'J. B. Selwyn to A. F. A. Carlisle', 2 I January I96I.

71 BOE, EID $3 / 363$, M. J. Thornton, 'Monetary surveys in IFS: UK page', I 8 February I959.

72 BOE, EID 3/363, W. M. Allen, 'International Financial Statistics', 20 February I959.

73 Stand-by facilities were in use after 1952 and provided borrowers with access to an agreed facility, without further consultation, for a specified period (usually a year).

74 The I96I drawing came after an 'IMF-friendly' statement by Chancellor Selwyn Lloyd. The I962, I963 and July I964 Letters of Intent were largely recapitulations of policy measures already undertaken by the UK government. The November I964 drawing was on an existing stand-by arrangement, so 'no new understandings were needed'; International Monetary Fund Archive, Washington, DC (hereinafter 'IMF'), EBM/64/57, R. L. Horne, 'Minutes of Executive Board meeting 64/57', 28 October I964; Clift and Tomlinson (2008), p. 552.

75 Schenk (2010), pp. I $87-8$.

76 TNA, T236/5740, 'Note to D. Rickett', 8 May I959. 
would-be borrower's macroeconomic policies and the collaborative development of a recovery program' (Finch I989, p. 9). By I958, the Fund had phased loans to Turkey, Yugoslavia, Bolivia, Haiti, Paraguay, Argentina and Chile with the implementation of financial programmes. These rules for developing nations were formalised in I958 when the IMF's Executive Board recommended that Bolivia be denied access to its loan facility while it remained in breach of the agreed programme. ${ }^{77}$ The performance targets included limiting central bank credit, chosen because the Fund believed the Bolivian central bank could control its balance sheet. This was the foundation for Polak's Western Hemisphere model.

The Western Hemisphere model was predicated on the theory that domestic credit creation was the primary source of balance of payments disequilibria. It was simple, designed for nations for whom the reliability and even existence of accurate financial statistics might be in doubt. ${ }^{78}$ It was too simple for British officials who could continue largely to ignore it until May I965, despite negotiating a succession of standby agreements and the large drawings of August I96I and November i964. In May I965, however, with the I964 stand-by fully drawn and \$I.I billion drawn from a $\$ 3$ billion facility provided by consortium of central banks falling due, the UK government requested an immediate \$I.4 billion loan that would take it beyond its quota. ${ }^{79} \mathrm{~A}$ drawing of this size required the Fund to activate the General Arrangements to Borrow negotiated two years earlier with its members. Given the more 'classical' monetary views held by a number of European central bankers, this meant tougher conditionality.

The May I965 IMF mission was led by Polak. While he conceded on a ceiling for Bank of England credit to the government, he insisted that 'estimates' for the growth of clearing bank lending and deposits be included in the Letter of Intent. ${ }^{80}$ While this did little to endear him to UK officials, it is noteworthy that Polak was prepared to target commercial bank lending and deposits rather than central bank lending. Previously, IMF performance criteria had almost always related to the central bank's balance sheet. ${ }^{81}$ Nonetheless the Fund recognised that the choice of ceiling depended on the characteristics of each country's monetary system - 'a ceiling

77 After I 8 months of wage restraint, the Bolivian government permitted a 30 per cent wage rise for its miners. The Fund had inserted a clause allowing for the suspension of Peru's drawing rights in February I954 (Horsefield I969, pp. 374, 433).

${ }_{78}$ For the development of the model over time, see Polak (I997), p. 4 and (200I), p. I.

79 IMF members were allocated a quota comprised of four tranches. The first tranche (the 'gold tranche') represented the member's contribution of assets other than its own currency, originally gold. Members drawing on the successive 'credit tranches' above the gold tranche could expect increasingly stringent conditionality. The November I964 drawing had taken the UK fractionally beyond its quota; the May I965 drawing took the UK to I97.4 per cent of quota (IMF, EBM 65/25, R. L. Horne, 'Minutes of Executive Board meeting 65/25', I2 May I965).

${ }^{80}$ In line with the Fund's statistical presentation in IFS, Polak initially proposed numerical ceilings on London clearing bank lending (TNA, T3I2/I387, J. J. Polak, 'Monetary policy', I4 April I965).

${ }^{81}$ Given the importance of commercial bank lending to the Egyptian cotton industry, an exception was made for the United Arab Republic's May 1964 facility (Middle Eastern Department, IMF, Executive 
applying to the banking system as a whole may be preferred because its relationship to other economic variables, and policy decisions, is clearer'. ${ }^{82}$ This sold the pass on conditionality attached to the growth of the monetary base. And having conceded in I962 that there was less distinction between current and deposit accounts in the UK than elsewhere, the pass was sold on conditionality applied to the growth of 'narrow money'.

Access to the 1965 facility was not phased according to performance criteria. Nonetheless, Chancellor James Callaghan undertook to consult the Fund 'should any major shift in the direction or emphasis of economic or financial policy as stated in this letter become desirable during the period in which Fund holdings of sterling are in excess of 125 per cent of the quota'. ${ }^{83}$ Since financial policy included 'an increase in advances to the private sector by the London clearing banks in the year ending March 1966 of not more than 5 per cent ( 230 million), and... an increase in their deposits in the same proportion (about f400 million)', the IMF had imposed loose monetary conditionality on the UK, albeit on a definition of UK officials' choosing. ${ }^{84}$ As Polak explained to the Fund's Executive Board:

In our discussions we have put primary emphasis on the importance of the Government taking a view as to the appropriate amount of credit expansion. We considered this more important than the introduction of one specific measure of control or another. ${ }^{85}$

\section{I}

On I7 November 1967, the British government finally admitted defeat in the defence of sterling at the post-I949 Bretton Woods parity of \$2.80. The Fund's managing director, Pierre-Paul Schweitzer, reacted 'without surprise and with little comment', despatching a mission led by its head of fiscal affairs, Richard Goode, to London

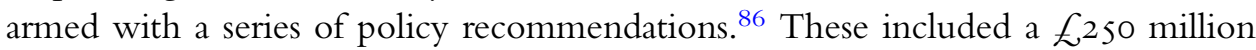
limit on Exchequer borrowing from the banking system and a f500 million

Board Specials (EBS) 64/69, 'United Arab Republic - request for a stand-by arrangement', 28 April I964).

82 IMF, Departmental Memoranda (DM) 67/5I, D. J. Cleary, 'The construction of credit ceilings: definitional aspects', I8 August I967; BOE, 5AI77/I, 'Credit ceilings in the United Kingdom', I3 February I969.

83 This was a quantitative rewording of a stipulation applied to the UK in I96I; IMF, EBS/6I/IO0, J. S. B. Lloyd, 'Policies and intentions of the government of the United Kingdom', 28 July I96I; IMF, EBS/65/69, 'L. J. Callaghan to P-P. Schweitzer', 27 April I965.

84 The Governor wrote to the main banking and finance associations requesting that they restrict lending through advances, acceptances and commercial bills to Ios per cent of the mid-March I965 level; IMF, EBS/65/69, 'L. J. Callaghan to P-P. Schweitzer', 27 April i965.

85 IMF, EBM/65/25, R. L. Horne, 'Minutes of Executive Board meeting 65/25', I2 May I965.

86 The Governor had recently warned the Fund that 'the United Kingdom no longer considered itself bound by an undertaking given in June I967 not to devalue within six months' (Schenk 20Io, pp. I90-I, I94). 
ceiling on domestic credit expansion. ${ }^{87}$ These, the Fund estimated, would be required to generate the desired current account surplus over the next year. Goode immediately ran into trouble. The Chancellor was naturally concerned about the political criticism IMF-imposed performance criteria would attract, both from the Conservative opposition and from his own backbenchers.

Bank and Treasury officials' concerns were more technical. They argued that if the market knew the authorities were missing an IMF target, they could be held to ransom, forced to pay a higher rate on the new gilt issues required to get Exchequer borrowing from the banking system and DCE back on track. The Issue Department's management of the national debt was perceived to be a fine art, not conducive to the blunt instrument of an IMF performance target. Moreover, as Maurice Allen pointed out, it was impossible to estimate in advance how much the EEA would have to borrow from the banks to finance an influx, especially given sterling's reserve currency status. ${ }^{88}$ Deputy Governor Sir Maurice Parsons also reminded Goode that British banking was traditionally reliant on overdrafts, which could be drawn at the convenience of the borrower. This made it very difficult for the clearing banks to predict the size of future lending and, therefore, their reserves at the Bank. In short, the size of the Bank's balance sheet, and DCE, simply could not be forecast with any degree of precision.

We tried to explain that it was wrong to apply to the UK with its sophisticated monetary system principles and practices which might be perfectly alright for the Argentine or a lesser-developed African country. But even after long sessions, we failed to convince Goode and we therefore agreed, in the course of the final session between [Permanent Secretary to the Treasury] William Armstrong and Goode, that between now and February we would have a seminar - presumably in London - which could discuss all these points thoroughly without being up against the clock, as we were in preparing the Letter of Intent. ${ }^{89}$

While Armstrong was prepared to forego an IMF loan rather than accept DCE conditionality, the Bank's Jeremy Morse conceded that 'as far as the Bank was concerned we would be ready to concede a "warning light" ceiling for money supply or for bank credit to the public sector the reaching of which would provoke immediate consultations with the Fund'. ${ }^{90}$ While this was little advance on the loose conditions included in the May i965 Letter of Intent, it helped to extricate the two sides from 'the familiar

87 IMF, F. A. Southard, 'UK matter: further conversations and developments - November I7-I 8', I967, European Department Records, European Department Division Files, EUR Divisions Country/ Country Desk files, United Kingdom, box 73, file 4/i66.

$88 \mathrm{BOE}, 4 \mathrm{Ai} 60 / 5$, W. M. Allen, 'IMF consultations', i9 November I967.

89 On 24 November, the French news agency L'Agefi reported that the talks had failed and the IMF team was returning to Washington; IMF, 'L. A. Whittome to Managing Director', 24 November I967, European Department Division Files, EUR Divisions Country Correspondence Files, United Kingdom, box 34, file I/32; TNA, T3 I2/I8 I9, 'D. F. Hubback to Maude', 24 November I967.

90 BOE, 4Ai6o/5, C. J. Morse, 'Fund mission', 2 I November I967. 
rut for UK-IMF dialogue about our monetary objectives'. ${ }^{91}$ After agreeing a form of words on the Exchequer borrowing requirement, the Fund conceded, once again, on the monetary target. As Maurice Allen noted:

the Mission offered us several different ways of binding ourselves to be good - sterilising the sterling receipts of EEA; varying the money supply ceiling up or down as the EEA went up or down, etc. Eventually, when they saw that we would not allow negotiations to be held up while we argued out at length such fundamental issues of principle, they accepted a modified version of Sir William Armstrong's draft mentioning the 'expectation that...the growth of the money supply [on our definition] will be less in I969 (sic) than the present estimate for 1967 both absolutely and as a proportion of GNP'. ${ }^{92}$

The 'present estimate' for I967/68 was EI.I23 billion, or about 81/2 per cent of the broad money stock. ${ }^{93}$ As head of the Economic Service, Sir Alec Cairncross later pointed out, Armstrong 'knew that the borrowing requirement was more important to [the IMF] than the credit ceilings' (Cairncross I997, p. 254). The 'fundamental issue of principle' would be discussed at a future date, outside the pressurised atmosphere of the loan negotiation. But the British had succeeded in keeping to their broad definition of the money supply.

\section{VII}

The next engagement was the 'DCE seminar', proposed by Armstrong, which finally took place in October I968. ${ }^{94}$ The IMF team was led, once again, by Polak. The terms of reference were: 'to examine the theory of the relationships of financial factors on the national income and balance of payments, and the implications of these relationships for the techniques of economic forecasting' (less formally, 'to strengthen the position of those in London who regard financial programming as a useful tool of policy'). ${ }^{95}$ On the first day the seminar considered two papers which defined 'money'; one from the Bank, the other from the CSO. ${ }^{96}$ Both were in

91 BOE, 4Ai60/5, W. M. Allen, 'IMF consultations', i9 November I967.

92 BOE, 4Ai6o/5, W. M. Allen, 'Fund consultations', 22 November 1967.

93 TNA, T326/730. The outturn was £986 million; 'IMF Letter of Intent: money supply', November I967.

94 Existing accounts of the (twice postponed) seminar include: Tew (I978), p. 247; Cairncross (I996), p. 220; James (I996), pp. I90-I; Capie (2010), pp. 396-8, 452-3; Needham (2014), pp. 24-5.

95 IMF, A. J. C. Edwards, 'Monetary seminar (International Monetary Fund): terms of reference and arrangements for the seminar', 7 October I968, European Department Immediate Office (EDIO), box I03, file I; IMF, L. A. Whittome, 'UK-Armstrong Exercise', I2 January I968, European Department Records, European Department Division Files, EUR Divisions Country Correspondence Files, United Kingdom, box 34, file 2.

96 The CSO's suggested definition also included deposits held at the Trustee Savings Banks and Post Office Savings Banks, IMF, Central Statistical Office, 'The definition of money supply', EDIO, box I03, file I, I07; IMF, Bank of England, 'Defining the money supply', I4 October I968, EDIO, box IO3, file I. 
line with the UK's traditional broad definition. The Fund conceded that 'what was important was to choose a definition which covered all points at which money could be injected into the system and which was not misleading as an indicator'. ${ }^{97}$ In any event, 'their prime concern was not with the money supply as such'; it was with domestic credit expansion - the topic of the second day's discussion. Polak explained:

the critical monetary factor in the forecasting process was domestic credit expansion. Preliminary figures could first be set (be it as forecasts or targets) for GNP and the balance of payments. Then, on the assumption of a stable income-velocity of circulation, a forecast could be made of the money supply. From the balance of payments (change in external assets) and money supply forecasts thus obtained, the figure for domestic credit expansion could be derived. The latter in turn could be regarded as a first approximation to the additional spending likely to be generated as a result of monetary factors. ${ }^{98}$

There was 'extended discussion' on the need to identify the source of the credit impulse. There were also considerable doubts expressed about the stability of the income-velocity of circulation, unsurprising at a seminar chaired by a member of the Radcliffe Committee (Sir Alec Cairncross) that had declared this to be 'potentially infinite' with another of its witnesses (Nicky Kaldor) in attendance. The principal disagreement, however, was whether the authorities should be looking at an aggregate measure such as DCE or its components. When asked what the UK reaction to an unforeseen increase in the money supply would be, Cairncross replied it would surely be prudent to investigate the reasons for it closely before taking any action beyond perhaps some upward adjustment in interest rates' ${ }^{99}$

There was less dispute over which measure of money should be used. Summing up on the final day, Polak conceded that 'the sensible course seemed to be to choose that definition of the money supply which gave the best correlation with money income and interest rates, and to extend the authorities' control to include all those institutions whose liabilities fell within this definition'. ${ }^{100}$ He had earlier noted that 'for the purposes of monetary policy, it was interesting to study what spectrum of assets gave the best correlation with GNP and interest rates'. ${ }^{101}$ Unbeknown to Polak, the Bank had already decided to do precisely this. Notwithstanding the broad money supply definition presented to the Fund, and deployed (with minor variations) in official publications since 1958 , there remained within the Bank 'a variety of views about the money

97 IMF, A. J. C. Edwards, 'Note of proceedings on opening day of seminar (Wednesday, I6th October I968)', EDIO, box I03, file I.

98 IMF, A. J. C. Edwards, 'Note of proceedings on second day of seminar (Thursday, I7th October I968)', EDIO, box I03, file I.

99 Ibid.

100 IMF, A. J. C. Edwards, 'Note of proceedings on final day of seminar (Monday, 2 Ist October, I968)', EDIO, box IO3, file I.

101 IMF, A. J. C. Edwards, 'Note of proceedings on opening day of seminar (Wednesday, I6th October I968)', EDIO, box I03, file I. 
supply'. ${ }^{102}$ Chief Cashier John Fforde concluded it was time for a review (Capie 20IO, pp. 452-9). ${ }^{103}$ Thus was born the Money Supply Group, comprised of Kit McMahon, Leslie Dicks-Mireaux, Andrew Crockett and, newly arrived from the London School of Economics, Charles Goodhart. This marked the onset of a fertile period of monetary research within the Bank, mirroring the theoretical investigations underway in academia. The group's work, however, was delayed by Chancellor Roy Jenkins' acceptance of DCE performance criteria in May 1969. The 1965 and I966 drawings from the Fund were falling due and, with the current account taking an inexorably long time to recover, the Bank had insufficient dollar reserves to repay. There was little alternative to another stand-by arrangement. In response to developing nations' protests about the lack of strict conditionality attached to the UK's I967 loan, the Fund had harmonised its stand-by criteria the previous September. There was little doubt that further assistance would require a DCE ceiling. ${ }^{104}$ While detailed negotiations had to wait until after the April I969 Budget, to avoid giving the impression that the IMF was dictating policy, a team of Bank and Treasury officials was despatched to Washington in February to sound out the Fund.

To some UK irritation, the Fund initially suggested a ceiling on the Bank of England's gross domestic assets, before retreating to 'the concept of domestic credit of the banking system as set out in the monetary survey of IFS'. ${ }^{105}$ As the Bank's Jasper Hollom pointed out, 'the broad lines on which the application of the Fund's concept to the UK should be based were agreed without much difficulty'. ${ }^{106}$ This may have been aided by pressure from the managing director who, in discussion with UK officials over the ceiling, admitted that 'the UK "must agree to something". ${ }^{107}$ But Schweitzer seemed flexible on what the 'something might be'. The Treasury's Frank Figgures explained that a ceiling based on the broader aggregate would make the Chancellor's job of presentation much easier. With some minor modifications (and despite their own equations showing a more robust relationship between narrow money and income), 'the Fund were perfectly content'. ${ }^{108}$

102 The impetus within the Bank came from the Governor; BOE, 5 Ai 75/I, C. W. McMahon, 'Money supply and the Quarterly Bulletin', 25 April I968; BOE, 5AI75/I, M. J. Thornton, 'Money supply', April I968.

103 The day before the seminar, The Times reported that the Bank was undertaking a 'close study' of the money supply, 'Understanding the role of money supply' (The Times, is October I968; BOE, 5Ai75/I, J. S. Fforde, 'The money supply', is October I968).

104 During the November I968 surveillance meeting, the Fund made it plain that 'quantified financial ceilings would be essential in connection with a [new] stand-by arrangement' (IMF, Staff Mission, 'Briefing paper: stand-by review', I5 November I968, UK Country Files, box I 5, file I).

105 IMF, P. Chabrier, 'The I969 stand-by with the United Kingdom', I 3 July I970, EUR Divisions, UK Country Desk Files, United Kingdom - Review of stand-by, January-July, I970, box 78, file I.

106 BOE, 5AI77/I, J. Q. Hollom, 'Discussions with the IMF on credit ceilings', 7 March I969.

107 TNA, T326/978, A. K. Rawlinson, 'IMF Standby: overall credit ceilings', I 3 February I969.

108 'UK DCE' differed from the IFS presentation by (i) excluding bank lending to residents in foreign currency for investment abroad, (ii) including bank lending in sterling to non-residents, (iii) 
There remained the thorny question of where to set the DCE ceiling. This involved some 'hard discussion', a trip by Financial Secretary Harold Lever to Washington, and a compromise whereby the performance criteria would be a commitment on the part of the UK's Executive Director at the Fund, rather than the Chancellor. This allowed Jenkins to say 'honestly that he had not committed to any performance criteria which the Fund staff might enumerate'. ${ }^{109}$ And instead of a breach of the ceiling triggering a visit from the Fund, Jenkins agreed to three further surveillance missions. These would take place regardless of the DCE outcome. As the Economist pointed out, 'the most important feature of $\mathrm{Mr}$ Jenkins's letter of intent to the International Monetary Fund is the thinness of the fig leaf that has been stretched over the trigger clause'. ${ }^{110}$ To further placate his critics, Jenkins pretended that DCE was a British invention. This created an unwelcome diversion for Bank and Treasury officials, forced to justify an aggregate initially designed for less developed nations that none of them believed had much relevance for the UK. As Goodhart explains: 'to protect British amour propre there had to be some pretence that we, in the UK, had thought up this wonderful new wheeze, rather than had it foisted upon us, out of weakness, by the IMF' (Goodhart 2003, p. 25). Articles by Bank and Treasury officials in I 969 studiously avoided the suggestion that DCE was anything other than a British initiative. ${ }^{111}$ The pretence worked, with British journalists and American observers taken in (Capie 20I0, p. 456).

\section{VIII}

In I982, John Fforde wrote:

Specific intermediate targetry was...first introduced in the United Kingdom when standby facilities were negotiated with the Fund following the devaluation of sterling in I967...The requirements of the IMF fitted readily into the established flow-of-funds accounting matrix and could thereby be made analytically consistent and visibly related. ${ }^{112}$

In I969 the IMF imposed a DCE ceiling on the reluctant British authorities (after insisting upon a money supply objective in 1967), but it was a broad variant that

including short-term sterling lending to local authorities from the overseas sector and (iv) including medium- and long-term borrowing from overseas by the public sector; IMF, Chabrier, 'The I969 stand-by', pp. 8-9; TNA, T326/978, A. K. Rawlinson, 'IMF standby: overall credit ceilings', I3 February I969; IMF, V. Argy, 'UK credit ceilings', Io April I969, European Department Records, European Department Division Files, EUR Divisions Country Correspondence Files, United Kingdom, box 34, file 3 .

109 TNA, T326/979, A. J. C. Edwards, 'Note for the record: Domestic Credit Expansion and the Central Government Borrowing Requirement', I2 May I969.

110 'Dear Mr Schweitzer', Economist, 28 June i969.

111 HM Treasury, 'Money supply and domestic credit: some recent developments in monetary analysis', Economic Trends, no. I87 (May I969), pp. xxi-xxv; 'Domestic Credit Expansion', BEQB, 9(3) (September 1969), pp. 363-75.

112 J. S. Fforde, 'Setting monetary objectives', BEQB, 23(2) (June I983), p. 20 I. 
fitted longstanding British characteristics. Specifically, it reflected the porous divide between current and deposit accounts. A narrow definition, more attuned to the IMF's Western Hemisphere model would have required root and branch overhaul of, inter alia, British banking, monetary policy, management of the national debt and the currency reserves, and national accounting conventions. Faced with British intransigence and the need to preserve the Bretton Woods system, the Fund was pragmatic in the choice of aggregate, albeit after losing a 'Seven Year's War' with the Bank's statisticians. Britain entered the economically turbulent I970s with the focus of monetary analysis and management on broad money with its link to fiscal policy through the credit counterparts. This approach would reach its apogee in the Thatcher government's I980 Medium-Term Financial Strategy, with its fouryear series of declining $\mathrm{f}_{3} \mathrm{M}_{3}$ target ranges and deficit ceilings.

Submitted: 28 March 2017

Revised version submitted: I4 August 2017

Accepted: 6 October 2017

\section{Sources}

Bank of England Archive, London

International Monetary Fund Archive, Washington DC

The National Archives, London

Bank of England Statistical Summary

Bank of England Quarterly Bulletin (BEQB)

Economic Trends

The Economist

Financial Statistics

Hansard

International Financial Statistics (IFS)

Midland Bank Review

\section{References}

ALFORD, R. F. G. (1986). Flow of Funds: A Conceptual Framework and Some Applications. Aldershot: Gower.

ALFORD, R. F. G. (2009). Life and LSE. Brighton: Book Guild Publishing.

ALLEN, W. A. (2OI2). Quantitative monetary policy and government debt management in Britain since I919. Oxford Review of Economic Policy, 28(4), pp. 804-36.

ALLEN, W. A. (2014). Monetary Policy and Financial Repression in Britain, 1951-59. Basingstoke: Palgrave Macmillan.

BAIN, A. D. (1973). Surveys in applied economics: flow of funds analysis. Economic Journal, 83(332), pp. I055-93.

BALOGH, T. (I950). Studies in Financial Organisation. Cambridge: Cambridge University Press.

BANK OF ENGLAND (I972). An Introduction to Flow of Funds Accounting: 1952-70. London: Bank of England.

BATINI, N. and NELSON, E. (2005). The UK's rocky road to stability. Federal Reserve Bank of St Louis Working Paper 2005-020A.

BELL, G. L. and BERMAN, L. S. (I966). Changes in the money supply in the United Kingdom, I954 to I964. Economica, 33(I30), pp. I48-65. 
BERMAN, L. S. and CASSEL, F. (I968). Short-term forecasts of income, expenditure and saving. Economic Trends, I72, pp. ix-xv.

BJORK, S. and OFFER, A. (20I3). Reconstructing UK Flow of Funds Accounts before 1987. Oxford: Winton Institute for Monetary History.

BOARD OF GOVERNORS OF THE FEDERAL RESERVE SYSTEM (I943). Banking and Monetary Statistics, 1914-1941. Washington, DC: Board of Governors of the Federal Reserve System.

BORDO, M. D., HUMPAGE, O. F. and SCHWARZ, A. J. (2015). Strained Relations: US ForeignExchange Operations and Monetary Policy in the Twentieth Century. Chicago: University of Chicago Press.

CAIRNCROSS, A. K. (I996). Managing the British Economy in the 1960s: A Treasury Perspective. Basingstoke: Macmillan.

CAIRNCROSS, A. K. (I997). The Wilson Years: A Treasury Diary 1964-1969. London: Historians' Press. CAPIE, F. H. (20 IO) The Bank of England: 1950s to 1979. Cambridge: Cambridge University Press.

CAPIE, F. H. and WEBBER, A. (I985). A Monetary History of the United Kingdom: 1870-1982, vol. I: Data, Sources and Methods. London: George Allen and Unwin.

CLIFT, B. M. and TOMLINSON, J. D. (2008). Negotiating credibility: Britain and the International Monetary Fund, I956-I976. Contemporary European History, I7(4), pp. 545-66.

DE BONIS, R. and GIGLIOBIANCO, A. (20 I2). The origins of financial accounts in the United States and Italy: Copeland, Baffi and the institutions. In R. De Bonis and A. F. Pozzolo (eds.), The Financial Systems of Industrial Countries. Heidelberg: Springer.

DORRANCE, G. S. (I955). Financial accounts in a system of economic accounts. IMF Staff Papers, 4(2), pp. 3I9-29.

DOW, J. C. R. (1970). The Management of the British Economy, 1945-60. Cambridge: Cambridge University Press.

DUDLEY EDWARDS, R. (I993). The Pursuit of Reason: The Economist 1843-1993. London: Hamish Hamilton.

FFORDE, J. S. (1992). The Bank of England and Public Policy, 1941-1958. Cambridge: Cambridge University Press.

FINCH, C. D. (I989). The IMF: the record and the prospect. Princeton Essays in International Finance I75.

FLETCHER, G. A. (I976). The Discount Houses in London. London: Macmillan.

GOODHART, C. A. E. (2003). A central bank economist. In P. Mizen (ed.), Central Banking, Monetary Theory and Practice. Cheltenham: Edward Elgar.

GOODHART, C. A. E. (2009). The continuing muddles of monetary theory: a steadfast refusal to face facts. Economica, 76(si), pp. 82I-30.

GOODHART, C. A. E. (20i6). Determining the quantity of bank deposits. The Basel Issue, Banking Perspectives available online at www.theclearinghouse.org/research/20I6/20I6-q2-bankingperspectives/determining-quantity-bank-deposits

GOODHART, C. A. E. (2OI7). The determination of the money supply: flexibility versus control. The Manchester School, 85, pp. 33-56.

GOODHART, C. A. E., BARTSCH, E. and ASHWORTH, J. (20i6). Central banks and credit creation: the transmission channel via the banks matters, Sveriges Riksbank Economic Review, 3, pp. $55-68$.

GOSCHEN, G. J. (I905). Essays and Addresses on Economic Questions. London: Edward Arnold.

HIGGONET, R. P. (I957). Bank deposits in the United Kingdom, I870-I9I4. Quarterly Journal of Economics, 7I(3), pp. 329-67.

HORSEFIELD, J. K. (I969). The International Monetary Fund, 1945-1965: Twenty Years of International Monetary Cooperation, vol. I: Chronicle. Washington, DC: International Monetary Fund.

HOTSON, A. C. (2010). British monetary targets, I976 to I987: a view from the fourth floor of the Bank of England. LSE Financial Markets Group Paper Series I90.

HOTSON, A. C. (20 I7). Respectable Banking: The Search for Stability in London's Money and Credit Markets since the Great Currency Crisis of 1695. Cambridge: Cambridge University Press.

HOWSON, S. K. (I980). Sterling's managed float: the operations of the Exchange Equalisation Account, I932-39. Princeton Studies in International Finance 46.

JAMES, H. (I996). International Monetary Cooperation since Bretton Woods. Oxford: Oxford University Press. 
KEYNES, J. M. (1930). A Treatise on Money. London: Macmillan.

MACMILLAN COMMITTEE (I93 I). Committee on Finance and Industry: Report ('Macmillan Report'). London: HMSO.

MEADE, J. E. (I934). The amount of money in the banking system. Economic Journal, 44, pp. 77-83.

NEEDHAM, D. J. (20 I4). UK Monetary Policy from Devaluation to Thatcher, 1967-82. Basingstoke: Palgrave Macmillan.

NEVIN, E. and DAVIS, E. W. (1970). The London Clearing Banks. London: Elek.

NOBAY, A. R. (1973). The Bank of England, monetary policy and monetary theory in the United Kingdom, I95 I-I97I. The Manchester School, 4I(I), pp. 43-58.

PHILLIPS, C. A. (1920). Bank Credit: A Study of the Principles and Factors Underlying Advances Made by Banks to Borrowers. New York: Macmillan.

POLAK, J. J. (I957). Monetary analysis of income formation and payments problems. IMF Staff Papers, 6(I) pp. I- -50.

POLAK, J. J. (I959). Financial statistics and financial policy. IMF Staff Papers, 7(I), pp. I-8.

POLAK, J. J. (I 997). The IMF model at forty. IMF Working Paper no. 97/49.

POLAK, J. J. (200I). The two monetary approaches to the balance of payments: Keynesian and Johnsonian. IMF Working Paper no. OI/IOO.

POLAK, J. J. and BOISSONNEAULT, L. (I960). Monetary analysis of income and imports and its statistical analysis. IMF Staff Papers 7(3), pp. 349-69.

RADCLIFFE COMMITTEE (I959a). Committee on the Working of the Monetary System: Report ('Radcliffe Report'). London: HMSO.

RADCLIFFE COMMITTEE (1959b). Committee on the Working of the Monetary System: Principal Memoranda of Evidence. London: HMSO.

RADCLIFFE COMMITTEE (1960). Committee on the Working of the Monetary System: Minutes of Evidence. London: HMSO.

SAYERS, R. S. (1938). Modern Banking. Oxford: Oxford University Press.

SAYERS, R. S. (I967). Modern Banking, 7th edn. Oxford: Oxford University Press.

SCHENK, C. R. (2010). The Decline of Sterling: Managing the Retreat of an International Currency, 1945-1992. Cambridge: Cambridge University Press.

SHEPPERD, D. K. (197I). The Growth and Role of UK Financial Institutions, 1880-1962. London: Methuen.

STEELE, G. R. (20I4). The credit counterparts of broad money: a structural base for macroeconomic policy. Economics Working Paper Series 20I4/OOI, Lancaster: Lancaster University Management School.

TEW, J. H. B. (1978). Monetary policy: part I. In F. T. Blackaby (ed.), British Economic Policy, 1960-74. Cambridge: Cambridge University Press.

TURNER, J. D. (20I4). Banking in Crisis: The Rise and Fall of Banking Stability, 1800 to the Present. Cambridge: Cambridge University Press.

WADSWORTH, J. E. (I973). The Banks and the Monetary System in the UK, 1959-1971. Abingdon: Methuen.

WITHERS, H. (I9I0). The English Banking System. Washington, DC: Government Printing Office. 